\title{
Development of a Short-Term Ozone Prediction Tool in Campo Grande-MS-Brazil Area Based on Meteorological Variables
}

\author{
Amaury de Souza*, Flavio Aristones, Hamilton Germano Pavão, Widinei Alves Fernandes \\ Institute of Physics, Federal University of Mato Grosso do Sul, Campo Grande, Brazil \\ Email: ${ }^{*}$ amaury.de@uol.com.br
}

Received 6 March 2014; revised 12 April 2014; accepted 18 April 2014

Copyright @ 2014 by authors and Scientific Research Publishing Inc.

This work is licensed under the Creative Commons Attribution International License (CC BY).

http://creativecommons.org/licenses/by/4.0/

(c) (i) Open Access

\begin{abstract}
The objective of this study was to develop a model to predict the concentration of ozone. The measurements of ozone were conducted at the Federal University of Mato Grosso do Sul. The predictor variables related to climate were supplied by Embrapa Gada de Corte. Analyses of the data show a strong correlation between ozone and wind speed $(0.75)$, humidity $(-0.64)$ and temperature (0.41), as the factors that affect levels of concentration ozone. The observed and predicted values of daily ozone had a correlation coefficient $(R)$ of 0.69 .
\end{abstract}

\section{Keywords}

\section{Regression Model, Meteorology, Ozone Prediction}

\section{Introduction}

Studies on the influence of air pollution on the quality of human life have been conducted with great intensity in recent years [1]-[11]. This study aimed to evaluate the effects of variables that affect air quality, and of which, some made a direct link between air pollution with mortality rates and respiratory diseases.

Atmospheric pollution is characterized basically by the presence of toxic gases and solid particles in the air. The main causes of this phenomenon are the disposal of certain types of industries (steel, petrochemicals, cement, etc.) and the burning of coal and oil in power plants, automobiles and domestic heating systems [2] [12]-[15].

In large urban areas, there are frequent days when the air reaches critical levels. Whether by wind or by the

*Corresponding author.

How to cite this paper: de Souza, A., Aristones, F., Pavão, H.G. and Fernandes, W.A. (2014) Development of a Short-Term Ozone Prediction Tool in Campo Grande-MS-Brazil Area Based on Meteorological Variables. Open Journal of Air Pollution, 3, 42-51. http://dx.doi.org/10.4236/ojap.2014.32005 
absence of temperature inversions, these are periods in which the ascending currents of air cease are important for cleaning of pollutants accumulated in the layers near the surface.

The effects on the environment and health of the population due to the emission of these pollutants, especially particulate materials, may not only be local. This is because the region depends on factors such as the topography surrounding the point of emission, weather conditions and nature of pollutants. This means that these pollutants could travel thousands of kilometers through the atmosphere, thus reaching communities far from the point of emission.

Leite (2005) [2], argues that relative low humidity and low velocity of winds are favorable climatic conditions for the high levels of pollutants found in large cities. However, when rainfall and winds are intense, there is dissipation of air pollutants.

In many cases of growing cities, uncontrolled and unplanned causes of air pollution indices are close to the limit recommended by the environmental legislation. In some cases, these rates are exceeded, causing a risk to the population of the city.

Ozone is a highly reactive chemical oxidant that induces various adverse health effects, also generating significant economic consequences. It can affect the respiratory system of humans and animals and can cause lung inflammation [16] [17]. It also impacts agricultural yields, as even low ozone concentrations are associated to foliar injury and crop loss [18]. Moreover, ozone can accelerate a material's decay and discoloration [17]. Additionally, ozone is a greenhouse gas and can lead to global warming by trapping infrared radiation emitted by the Earth surface (National Research Council, 1991).

The European Union (EU) has established air quality standards regarding the ambient ozone concentration. Directive 2008/50 defines information and alert thresholds that refer to hourly values and are equal to 180 and $240 \mu \mathrm{g} \cdot \mathrm{m}^{-3}$. The same Directive also defines a guideline for the protection of human health. According to the Directive, the daily maximum 8-hour mean value should not exceed the target value of $120 \mu \mathrm{g} \cdot \mathrm{m}^{-3}$ in more than 25 days per calendar year in a three-year period.

For Brazil, according to Resolution 003 of the 1990 National Council on the Environment-Conama, the primary and secondary standard is $160 \mathrm{ug} / \mathrm{m}^{3}$ or about $81.2 \mathrm{ppb}$.

Several studies have been conducted aiming to develop tools capable to achieve a short-term forecast of ozone levels. Some of them are cited in Table 1, found later in this paper. The analysis often focuses on investigating whether or not a threshold is exceeded. Such information could be exploited by environmental and medical authorities to announce public health warnings. A common method is widely used when developing prediction models is to correlate meteorological and pollution data with the concentrations of a certain pollutant. The parameters used in analytical modeling are chosen so as to represent the meteorological conditions that don't favor the dispersion of pollutants to a certain degree, and the short-term variations in emissions.

The objective of this study is to develop an analytical model in order to produce the forecast of the next day's daily hourly value of ozone concentration in Campo Grande, MS, Brazil. The model relates the forecasted ozone concentration in Campo Grande, with various meteorological and pollution variables. This is the first paper in the international literature that deals with the ozone levels and their prediction in Campo Grande, where ozone monitoring has just recently been started. Additionally, it is the first study that examines the relation between ozone levels and meteorology in the area. The study of this relationship in Campo Grande is interesting as the greater area is characterized by complex topography that influences air flows and consequently pollution levels.

\section{Methods}

The city of Campo Grande, MS (20²7'16"S, 54 $\left.47^{\circ} 16^{\prime \prime} \mathrm{W}, 650 \mathrm{~m}\right)$, is located on the plateau called Campo GrandeMaracaju, $150 \mathrm{~km}$ to the start of the largest floodplain in the world, the Pantanal $\left(139,111 \mathrm{~km}^{2}\right.$ area). The climate in the region of Campo Grande has moderate temperatures ranging from $17.8^{\circ} \mathrm{C}$ minimum, maximum $29.8^{\circ} \mathrm{C}$, and average $22.7^{\circ} \mathrm{C}$. The lulls represented $12 \%$, with an average speed of $3.1 \mathrm{~m} / \mathrm{s}$. The average monthly rainfall is $122.4 \mathrm{~mm}$ with an annual average of $1469 \mathrm{~mm}$ [18] (Figure 1).

Information on daily levels of ozone $\left(\mathrm{O}_{3}\right)$ was obtained from the Institute of Physics of UFMS. The Ozone Analyzer, used to perform the measurements has the working principle of the absorption of ultraviolet radiation by ozone molecule. The analyzer is installed near Campo Grande, away from local resources. The measurements are performed continuously 24 hours per day, and every 15 minutes, values are given of the ozone concentration. Then, when the arithmetic mean was calculated per day, it was assumed that this estimate was representative of 

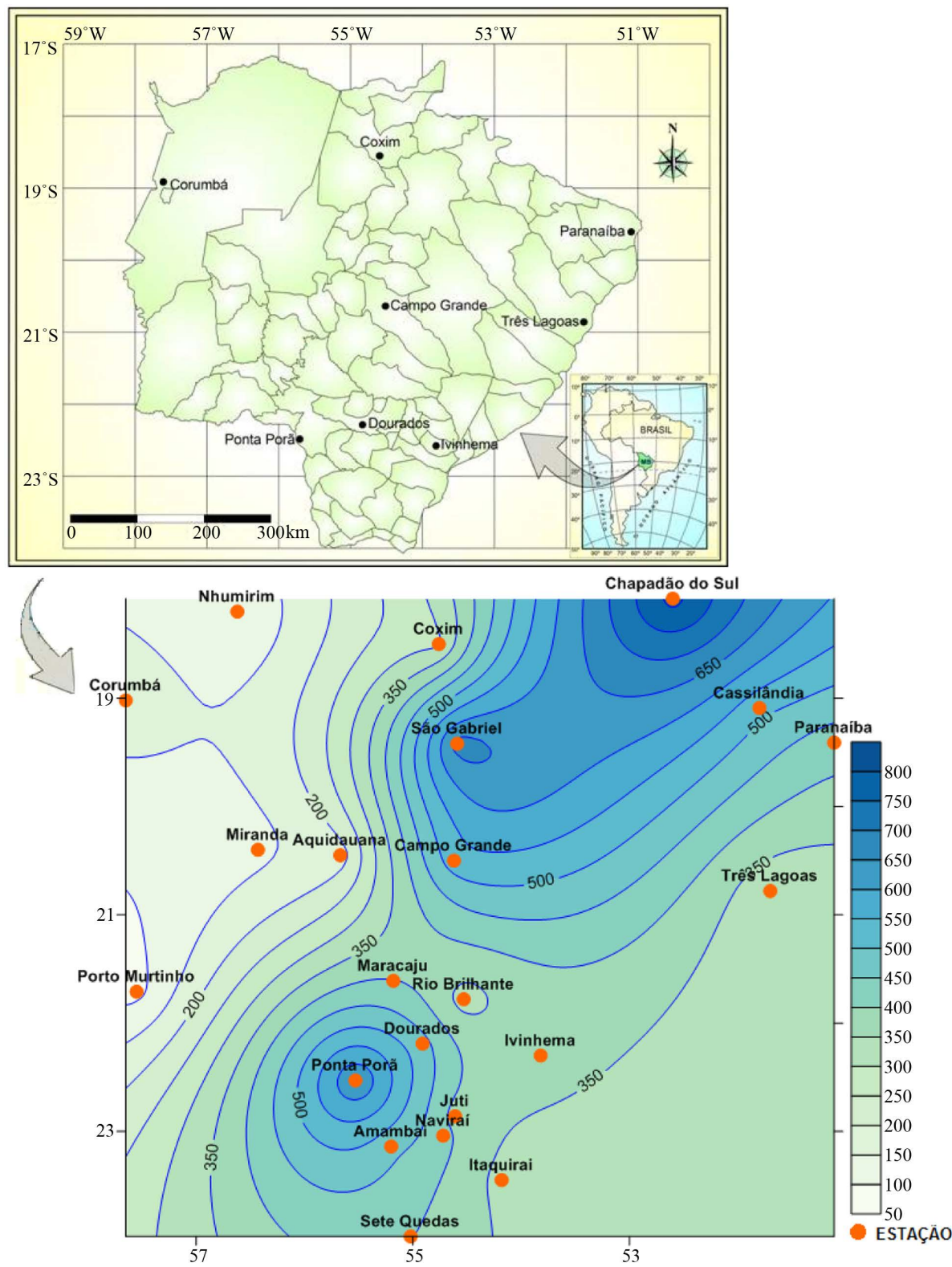

Figure 1. Location Space, latitude, longitude, altitude of the city of Campo Grande, MS Brazil used in this study.

air pollution in the city of Campo Grande. Information on rainfall, average temperature and relative humidity were obtained from Embrapa-Gado de Corte-Campo Grande.

In this study we performed a descriptive analysis of variables and, subsequently, were associated with ozone concentration data, the climatic variables rainfall, maximum temperature, relative humidity and wind speed, for the period 2004 to 2008.

To assess how meteorological conditions affect variations in ozone levels, the authors used multiple linear regression analysis. This is one of the most widely used methods for predicting how ozone concentrations depend on meteorological factors. The general equation for the model was as follows:

$$
Y=\beta_{0}+\beta_{1} X_{1}+\beta_{2} X_{2}++\ldots+\beta_{k} X_{k}+\varepsilon
$$

where $Y$ is an objective variable (ozone concentrations); $\beta_{0}, \beta_{1}, \beta_{2}$ and $\beta_{k}$ is the number of independent variables (meteorological variables) and are regression coefficients (estimated using the least squares procedure); $\varepsilon$ is an 
error term associated with the regression analysis.

The Mean Standard Error (MSE) was used after equations were linearized to check predicting hospital admissions:

$$
E Q M=\sqrt{\frac{1}{n}\left(\sum_{i=1}^{n}\left(P_{i}-O_{i}\right)^{2}\right)}
$$

where $P_{i}$ is the admissions estimate, $O_{i}$ is the admissions that actually occurred and $n$ is the sample.

\section{Results and Discussion}

Ozone concentrations in the greater Campo Grande area remain at relatively low levels. The maximum hourly value and the maximum 8-hour mean value observed at the monitoring site during the study period equal to 157 and $130 \mu \mathrm{g} \cdot \mathrm{m}^{-3}$ respectively, while the daily maximum 8-hour mean value exceeds the target value of 120 $\mu \mathrm{g} \cdot \mathrm{m}^{-3}$ in 9 days. Since the station is located in the city suburbs, it is expected to detect ozone concentrations at a higher level compared to those in the city centre. It is well known that ozone levels are higher in the suburbs than in the city centers. Ozone is a secondary pollutant. Ozone precursors are usually released in the city center and are usually transported by the wind to the suburbs where ozone is produced. Additionally, the absence of significant local sources of nitrogen monoxide in the suburbs results to the weakening of ozone destruction processes.

The frequency distribution of ozone concentration is presented in Figure 2. The highest frequency of occurrence is observed around the 25th percentile value that equals to $11.6 \mathrm{ppb}$. The skewness and kurtosis of the distribution are both 1.2. Since they are not zero, the normal distribution does not fit well the distribution of ozone concentrations. This conclusion is in accordance with other studies that have concluded that the most popular distribution used for fitting air pollutant concentration including ozone is the log-normal distribution [19] [20]. Additionally, the value of the 75th percentile is quite high (22.4 ppb) and not exceeds the phytotoxicity limit of $32 \mathrm{ppb}$, indicating that the background ozone levels can be relatively high. Ozone levels at the suburbs of Campo Grande do not present a significant weekly variation (not shown here), a fact indicating that they are not strongly affected by the weekly variation of the city activities.

In addition to emissions, the following atmospheric processes are influencing ozone concentrations: 1) the chemical reactions between the ozone precursor species (emitted from anthropogenic activities and natural processes) which occur under the effect of solar radiation; 2) the dry and wet deposition; 3) the advection by the horizontal wind; and 4) the vertical dilution within the boundary layer due to turbulence. It is thus important that the variables considered as predictors of ozone levels can cover these atmospheric processes. Following is the description of the variables considered in the development of the ozone levels forecasting tool. The variables

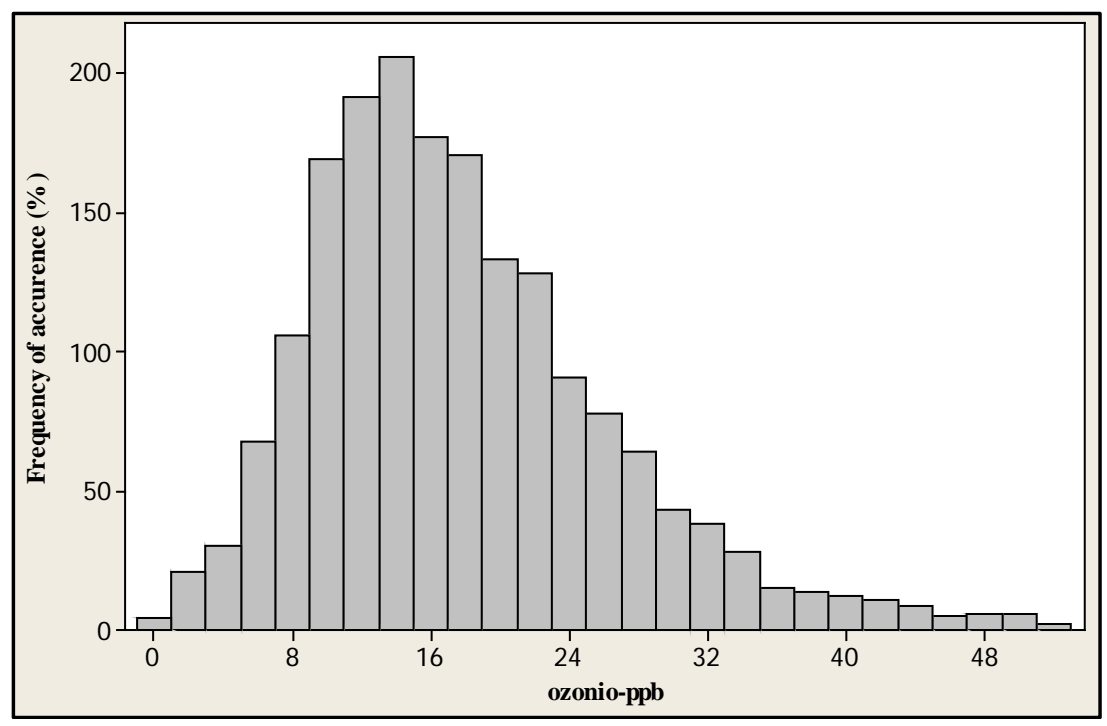

Figure 2. Frequency distribution of ozone concentration. 
were selected in order to represent most of the above atmospheric processes while taking into consideration at the same time the meteorological and air quality variables measured at the monitoring station located in the suburbs of Campo Grande.

Air temperature can be considered as a reasonable surrogate for the combined effects of wind speed, wind direction, inversion height and chemical reaction rate on ozone levels for two main reasons: 1) high air temperatures are an indication of environmental conditions conducive to ozone production and accumulation (i.e., anticyclonic conditions with associated clear skies and light winds); 2) the rate constants of chemical reactions are highly temperature dependent.

Ozone levels are also strongly affected by the intensity of the incoming solar radiation in the troposphere, where they are related with the complex photochemical cycles that produce ozone and with the growth of the atmospheric boundary layer (ABL) which in turn exerts a complex influence on pollutant levels in the lower troposphere.

The ozone concentrations are strongly related to the total solar radiation, verifying that increased solar radiation flux is associated to higher ozone concentrations. Despite this fact, the solar radiation is not selected as one of the variables included in the forecasting tool developed. Instead, the near-surface air temperature is selected as a surrogate of the solar radiation that reaches Earth's surface given also the more complete temperature dataset available compared to that of the solar radiation. The above suggest that air temperature may have the strongest correlation with ozone concentrations of all meteorological variables and can be considered as one of the most important variables for forecasting the ambient ozone levels. This assumption is verified by Figure 3, where ozone is plotted in relation to near surface air temperature. The correlation coefficient between the two parameters is equal to 0.41 .

High relative humidity and wet and rainy weather are usually associated with low ozone concentrations due to a reduction of photochemical efficiency and an increase of ozone deposition on water droplets [21] [22]. It is well known that relative humidity is negatively correlated with temperature, which can be considered as one of the primary ozone predictors. Ambient humidity affects the minimum temperature via two mechanisms [23]. Firstly, via the absorption of long-wave radiation emitted by the earth that would otherwise, under dry and cloudless conditions, be lost to space and secondly, via the release of the latent heat of condensation as the sensible temperature falls to the dew point. Figure 4 shows that high values of ozone concentrations are associated with low relative humidity values $(\mathrm{R}=-0.64)$.

Regarding the percentages of occurrence of daily doldrums and the intensity of the winds at the surface, it appears that, between May and September, the lowest values and the highest values occur, respectively. This is iustified by the higher frequency of entering polar air masses by promoting a greater variation in pressure gradients. This fact reduces the residence time of particles in the atmosphere, but increases the chance of fires by increasing the oxygen flow. The distribution of the directions of the winds at 10 meters in height and intensity has a predominant direction of north and northeast, with an intensity of $2.06 \mathrm{~m} / \mathrm{s}$.

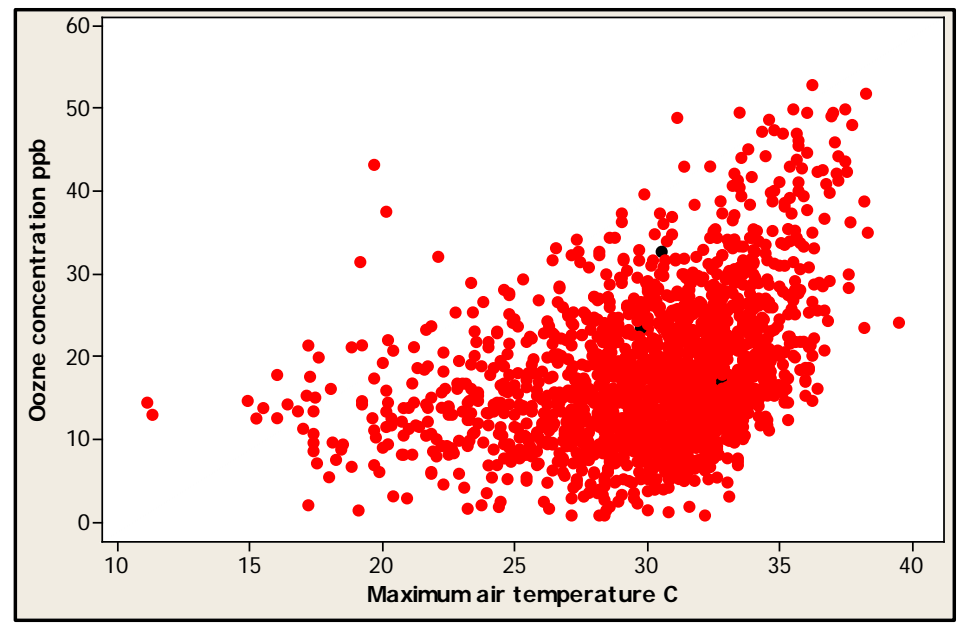

Figure 3. Dispersion of the ozone concentration in relation to temperature near the surface. 


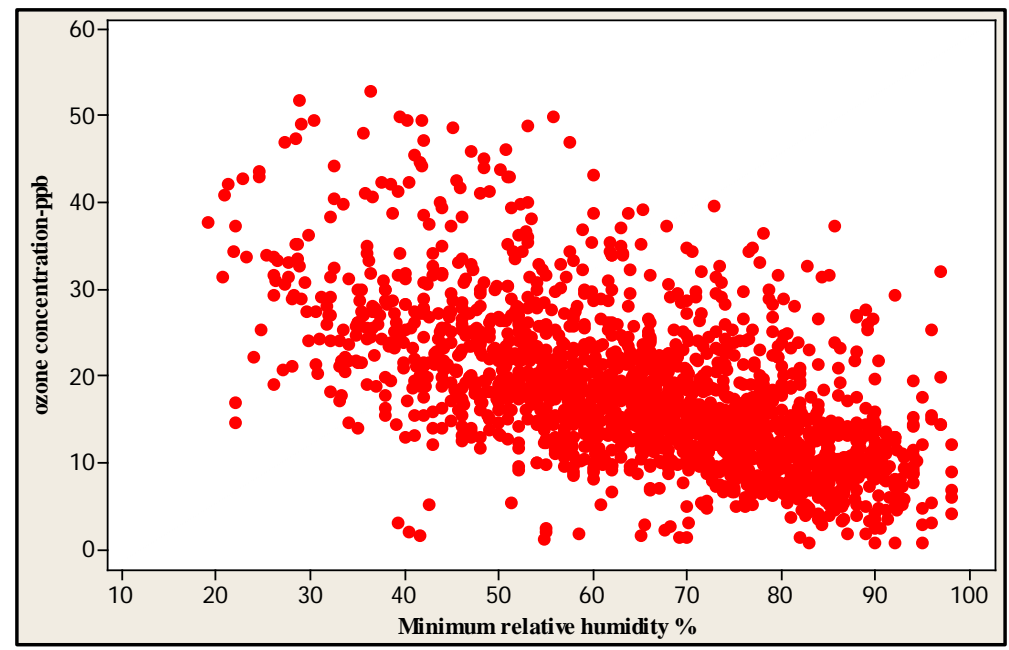

Figure 4. Scatter plot of ozone concentration in relation to daily values of relative humidity.

According to LIMA et al. (1996) [24], atmospheric circulation over South America significantly modifies the winter season to summer, especially at the higher levels $(250 \mathrm{hPA})$. At low levels, the flow pattern does not change significantly from summer to winter. In winter, there is the center of the South Atlantic Subtropical Anticyclone (SASH) closest to the South American continent intensifying winds on the northeast coast of Brazil, and is located more to the east in the summer. In high levels, in winter, the flow pattern is zonal, with an anticyclonic circulation over the northwest of South America, whose center is positioned at approximately $5^{\circ} \mathrm{S}$. The jet stream from the west is fairly intense, with the center of maximum speed the order of $45 \mathrm{~m} / \mathrm{s}$, located between $20^{\circ} \mathrm{S}$ and $40^{\circ} \mathrm{S}$. The main features of the flow at high levels in summer are similar to a wavelike pattern and present a strong anticyclonic center over Bolivia, known as the Bolivian High. Observational studies suggest that the development of the Bolivian High, in summer, is associated with strong warming of the Earth's surface over the Bolivian Altiplano during this time of year, heating the tropospheric column and thus causing an increase in atmospheric thickness on the continent at this point, thus generating a cyclone at high levels. In addition, the moisture convergence at low levels from the humid air masses to the north/northeast (Amazon region) and east (Pantanal), reinforce the convection and hence the release of latent heat of condensation in the middle and upper troposphere [25], increasing rainfall over the Amazon region and the central part of Brazil and fueling the anti-cyclone high pressure Bolivian High. Opposite conditions occur in winter, when the region of upward movement over the Amazon in summer migrates to the extreme northwest of the South American continent, being located on Venezuela and Colombia in May and June. In this work, the major interest is in the low-altitude jets $(850 \mathrm{hPa})$ which are winds that extend north along the Andes from northern Peru through Brazil to the east of Bolivia towards the River Plate basin. These jet streams that cross the region of Mato Grosso do Sul-Campo Grande, have an important role in the modulation of rainfall during the summer [26] and transport of pollutants during the winter [27]. In the summer, the region is dominated by the surface of the Chaco Low and High by Bolivia at high levels. These systems coupled dynamically move north during the winter. The winter season has characteristically dry cooler temperatures due to the frequent intrusion of cold air masses originating from the south extratropical areas. The squall lines occur both in summer, associated with low levels of convergence, as in winter, anticipating the penetration front. During the summer, the region of Campo Grande receives winds from the north of systems that form over the Amazon region primarily a result of the convergence of the trade winds from the northeast. In winter, there is a movement westward toward the mainland, the South Atlantic Subtropical Anticyclone and displacement to the north of the Intertropical Convergence Zone displacing moisture for remote areas north and northwest of the Amazon. Figure 5 shows that the high levels of concentration of ozone is associated with the wind speed values $(r=0.75)$.

As it has already been mentioned above, meteorology plays an important role in determining pollution levels. However, except for the meteorological factors, there are some other variables that could also be considered as predictors of pollution levels. Earlier studies have shown that the possibility of occurrence of a pollution episode is increased when the previous day's pollution levels were higher than normal [28] [29]. 


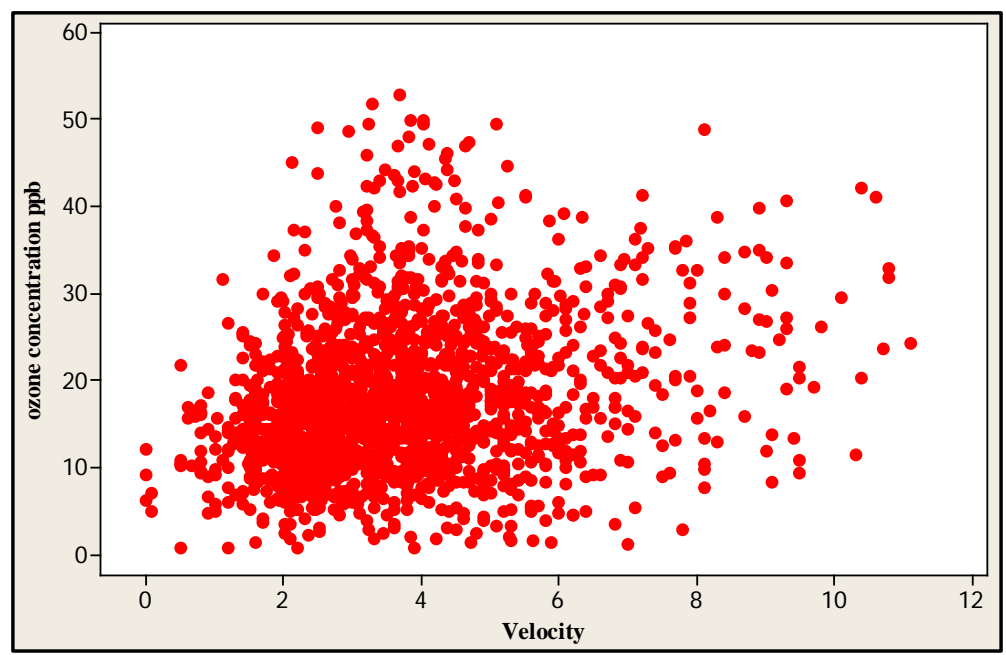

Figure 5. Dispersion of the ozone concentration in respect of speed of the wind daily.

This is attributed to the fact that pollution episodes are "built up" when meteorological conditions favoring high pollutant concentrations occur during successive days. The persistency of pollution levels could be also attributed to the daily cycle of the ABL.

Atmospheric pollutants are usually retained within the residual layer after the ABL's destruction at the end of the previous day. After sunrise, when the nocturnal boundary layer starts to be destructed and the ABL starts to develop, a mixing of the low atmospheric layers air with that of the upper layers occurs. Near surface air is less polluted than the air aloft as city activities have just started. Therefore, this vertical mixing can result in an increase in the near surface pollution levels. The more polluted the air that is trapped within the residual layer, the more significant the physical processes described above are. Additionally, the downward transport of ozone or ozone precursors from aloft could result in the production and increase of near surface ozone values (Figure 6). reveals that the of ozone concentration in the Campo Grande are significantly correlated to the respective values of the previous day, as the correlation coefficient equals to 0.63 . Therefore, the persistency of ozone levels is an important atmospheric process that has to be accounted for in the forecast of the peak ozone concentrations.

To assess how meteorological conditions affect variations in ozone levels, the authors used multiple linear regression analysis. This is one of the most widely used methods for predicting how ozone concentrations depend on meteorological factors. The general equation for the model was as follows:

$$
Y=22.3+0.345 X_{1}-0.268 X_{2}+0.726 X_{3}+6.74
$$

The values of the four constants, $\beta_{1}, \beta_{2}, \beta, b$, which are included in the prediction tool, are equal 0.345 to temperature; -0.268 to humidity, 0.726 to velocity and $\beta_{0}=22.3$, respectively. The average quadratic error between the estimated and observed value is 6.74 .

According to the multiple linear regression analysis, the model of ozone concentration, during the course of the analysis, was stable.

The forecast capability of the present study developed tool is compared with similar studies for Southern Europe. The study areas as well as information on the forecasting capability of previous models that were developed by applying regression analysis are presented in Table 1 . Table 1 confirms that the developed tool for Campo Grande is included among the most successful ones, as it explains 66\% of ozone observed variability. Additionally, the present study is in line with that of Kovac-Andric, E., Brana, J., Gvozdic, V., [30] regarding the number of predictors used. Both studies suggest that the short term ozone levels can be sufficiently predicted even if a small number of independent variables are utilized. Kovac-Andric, et al., [30] using humidity, temperature and wind speed in their model achieved to explain $77 \%$ of ozone variance during summer. Moreover, the present study is in line with those studies that report the correlation coefficients between ozone concentrations and independent variables.

$\mathrm{T}$ test was performed (based on the Studentt delivery) to test the significance of the coefficients in the equa- 


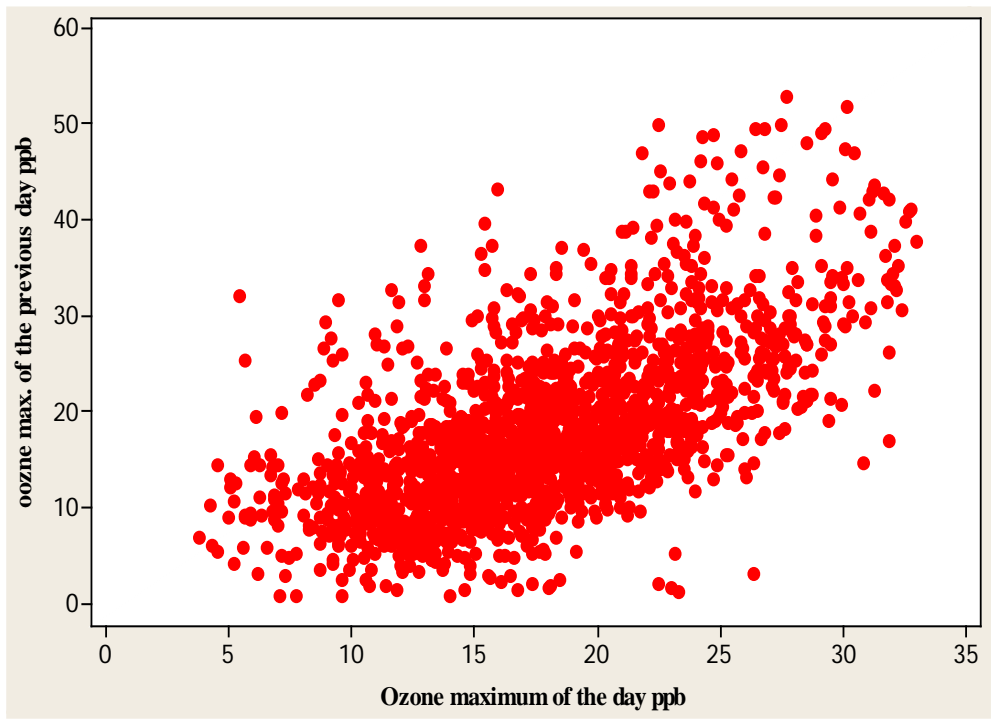

Figure 6. Scatter plot of the concentration of ozone in the previous day.

Table 1. Review of studies that aimed to predict short term ozone levels in South Europe.

\begin{tabular}{cccccc}
\hline & Site Information & Number of & \multicolumn{2}{c}{ Correlation of ozone with } & Variance \\
\hline Reference Paper & City/Country & predictors used & Temperature & Previous day's ozone & Explained (\%) \\
\hline Kovac-Andric et al., 2009 [30] & Osijek/Croatia & 3 & Not reported & Not reported & 77 \\
Chaloulakou et al., 1999 [31] & Athens/Greece & 7 & Not reported & Not reported & 43 \\
Ziomas et al., 1995 [32] & Athens/Greece & 6 & Not reported & Not reported & 59 \\
$\begin{array}{c}\text { Papanastasiou and Melas, } \\
\text { 2008 [33] }\end{array}$ & Volos/Greece & 7 & 0.75 & 0.90 & 86 \\
Sousa et al., 2007 [34] & Oporto/Portugal & 5 & Not reported & Not reported & 49 \\
Barrero et al., 2006 [35] & Errenteria/Spain & 6 & 0.38 & 0.70 & 60 \\
Tecer et al., 2003 [36] & Istanbul/Turkey & 8 & 0.48 & 0.48 & 71.5 \\
Di Carlo et al., 2007 [23] & L'Aquila/Italy & 4 & 0.43 & Not reported & 62 \\
\hline
\end{tabular}

tions. The results show that regression coefficients for speed, temperature, humidity, rainfall and wind are statistically significant. The values for the two coefficients are less than 0.05 (p-value $<0.5$ ). Ozone concentrations provided by statistical regression equation were plotted against the observed values, and the model explains $63 \%$ of the values. The results of the high correlation of this analysis indicate that ozone concentrations are strongly affected by weather. The correlation coefficients between ozone and wind speed was 0.75 , with the humidity -0.64 and temperature 0.41 .

\section{Conclusions}

This study provides information about ozone levels in the suburbs of Campo Grande, MS, Brazil during the period January 2004-December 2008 and presents the development of a short-term forecasting tool that could be exploited to predict peak ozone levels in the area. It is worth mentioning that to the knowledge of the authors, this is the first relevant study conducted for Mato Grosso do Sul. The main conclusions of this study are as follows:

Ozone levels in Campo Grande do not exceed the air quality standards in force.

The analysis reveals that the most significant variables in predicting the ozone concentration surface are air temperature, humidity and velocity.

The developed model is capable of explaining $63 \%$ of the variability in the observed ozone concentrations. Its 
reliability was evaluated against observational ozone data with the calculation of several statistical indexes. All the statistical measures examined take very satisfactory values suggesting a good agreement between modeled and observed values. Both the levels and the variance in observed ozone values are well reproduced by the model.

The use of simple meteorological variables, available from routine measurements, together with pollution measurements, may give rather good ozone level predictions in the study area. Since the model equation derived is simple, it can be used easily for operational forecasts. It should be noted that the success of the predictions depends strongly on the accuracy of the temperature forecast. However, since forecasted meteorological data were not available, this factor of uncertainty was not possible to be further examined in our study.

\section{References}

[1] Gutjahr, M.R. (2002) A Poluição do ar em Paulínia—SP: Uma análise histórico-geográfica do clima. Tese (Doutorado em Geografia Física). Pós-graduação em Geografia Física, Universidade de São Paulo—São Paulo-SP, 239 p.

[2] Leite, N.O. (2005) Modelagem estatística da relação entre poluição atmosférica e mortalidade por doenças respiratórias. Dissertação (Mestrado em Estatística e Experimentação Agropecuária)—Universidade Federal de Lavras, Lavras, MG, $64 \mathrm{p}$.

[3] Martins, L.C. (2002) Poluição atmosférica e atendimentos por pneumonia e gripe em São Paulo, Brasil, Revista Saúde Pública, 36, 88-94. http://dx.doi.org/10.1590/S0034-89102002000100014

[4] Peiter, P. and Tobar, C. (1998) Poluição do ar e condições de vida: Uma análise geográfica de riscos à saúde em Volta Redonda, Rio de Janeiro, Brasil. Cadernos de Saúde Pública, 14, 473-485. http://dx.doi.org/10.1590/S0102-311X1998000300003

[5] Schwartz, J. and Dockery, D.W. (1992) Particulate Air Pollution and Daily Mortality in Steubenville, Ohio. American Journal of Epidemiology, 135, 12-19.

[6] Schwartz, J. (1999) Air Pollution and Daily Mortality in Birmingham, Alabama. American Journal of Epidemiology, 137, 1136-1147.

[7] Gouveia, N. and Fletcher, T. (2000) Time Series Analysis of air Pollution and Mortality: Effects by Cause, Age and Socioeconomic Status. Epidemiology Community Health, 54, 750-755. http://dx.doi.org/10.1136/jech.54.10.750

[8] Lima, L.P. (2001) Modelos aditivos generalizado: Aplicação a um estudo epidemiológico ambiental. Dissertação (Mestrado em Estatística)—Universidade de São Paulo, São Paulo, SP.

[9] Fokianos, K. and Kedem, B. (2004) Partial Likelihood Inference for Time Series Following Generalized Linear Models, Jounal of Time Series Analysis, 25, 173-197. http://dx.doi.org/10.1046/j.0143-9782.2003.00344.x

[10] Morettin, P.A. and Toloi, C.M.C. (2004) Análise de séries temporais. Edagrd Blucher, São Paulo, 535 p.

[11] Lima, E.A.P., Guimarães, E.C., Pozza, S.A., Barrozo, M.A.S. and Coury, J.R. (2009) A Study of Atmospheric Particulate Matter in a City of the Central Region of Brazil Using Time-Series Analysis. International Journal of Environmental Engineering, 1, 80-94. http://dx.doi.org/10.1504/IJEE.2009.026444

[12] Cooper, C.D. and Alley, F.C. (2002) Air Pollution Control: A Design Approach. Waveland Press, Long Grove, 738 p.

[13] Theodore, L. (2008) Air Pollution Control Equipment Calculations. John Wiley \& Sons Inc., Hoboken, 574 p. http://dx.doi.org/10.1002/9780470255773

[14] Schifftner, K.C. (2002) Air Pollution Control Equipment Selection Guide. Lewis Publishers, Boca Raton, 228 p. http://dx.doi.org/10.1201/9781420031737

[15] Wark, K., Warner, C.F. and Davis, W.T. (1998) Air Pollution: Its Origin and Control. 3rd Edition, Addison Wesley Longman Inc., Menlo Park, 573 p.

[16] Cole, S. (1996) Lung Damage Linked to Combined Fine-Particle, Ozone Exposure in New Toxicology Study. Environmental Science and Technology, 30, 382A. http://dx.doi.org/10.1021/es962389p

[17] Heinsohn, R.J. and Kabel, R.L. (1999) Sources and Control of Air Pollution. Prentice Hall, New Jersey, 696.

[18] Krupa, S.V., Tonneijck, A.E.G. and Manning, W.J. (1998) Recognition of Air Pollution Injury to Vegetation: A Pictorial Atlas, Air and Waste Management Association, Pittsburgh, Pennsylvania, 2.1-2.28.

[19] Souza, A., Pavão, H.G., Lastoria, G., Gabas, S.G., Paranhos Filho, A.C. and Cavazzana, G.H. (2009) Distribuição espacial da relação precipitação/número de dias de chuvas em Campo Grande-MS. Seminário de recursos hídricos da bacia hidrográfica do Paraíba do Sul, Taubaté.

[20] Nali, C., Ferretti, M., Pellegrini, M. and Lorenzini, G. (2001) Monitoring and Biomonitoring of Surface Ozone in Florence, Italy. Environmental Monitoring and Assessment, 69, 159-174. http://dx.doi.org/10.1023/A:1010749722546 
[21] Lu, H.C. (2003) Comparisons of Statistical Characteristic of Air Pollutants in Taiwan by Frequency Distribution. Journal of the Air and Waste Management Association, 53, 608-616. http://dx.doi.org/10.1080/10473289.2003.10466194

[22] Lelieveld, J. and Crutzen, P.J. (1990) Influences of Cloud Photochemical Processes on Tropospheric Ozone. Nature, 343, 227-233. http://dx.doi.org/10.1038/343227a0

[23] Di Carlo, P., Pitari, G., Mancini, E., Gentile, S., Pichelli, E. and Visconti, G. (2007) Evolution of Surface Ozone in Central Italy Based on Observations and Statistical Model. Journal of Geophysical Research: Atmospheres, 112, Article Number: D10316. http://dx.doi.org/10.1029/2006JD007900

[24] Hubbard, M.C. and Cobourn, W.G. (1998) Development of a Regression Model to Forecast Ground-Level Ozone Concentration in Louisville, KY. Atmospheric Environment, 32, 2637-2647. http://dx.doi.org/10.1016/S1352-2310(97)00444-5

[25] De Lima, M.C. (1966) Manutenção da circulação atmosférica sobre a América do Sul. Tese de Doutorado em Meteorologia-INPE, $222 \mathrm{p}$.

[26] Fisch, G., Marengo, A.J. and Nobre, C.A. (1998) Clima na Amazônia. ACTA Amazônica, 28, 101-126.

[27] Fearnside, M.P. (2004) A água de São Paulo e a floresta amazônica. Ciência Hoje, Volume de abril de, 63-65.

[28] Aires, C.B. (2001) Avaliação de contaminantes produzidos em locais de queimadas e transportados para regiões onde não se queima. Tese de Doutorado em Geofísica Espacial-INPE, 117 p.

[29] Robeson, S.M. and Steyn, D.G. (1990) Evaluation and Comparison of Statistical Forecast Models for Daily Maximum Ozone Concentrations. Atmospheric Environment Part B-Urban Atmosphere, 24, 303-312. http://dx.doi.org/10.1016/0957-1272(90)90036-T

[30] Ziomas, I.C., Melas, D., Zerefos, C.S., Bais, A.F. and Paliatsos, A. (1995) On the Relationship between Peak Ozone Levels and Meteorological Variables. Fresenius Environmental Bulletin, 4, 53-58.

[31] Kovac-Andric, E., Brana, J. and Gvozdic, V. (2009) Impact of Meteorological Factors on Ozone Concentrations Modelled by Time Series Analysis and Multivariate Statistical Methods. Ecological Informatics, 4, 117-122. http://dx.doi.org/10.1016/j.ecoinf.2009.01.002

[32] Chaloulakou, A., Assimacopoulos, D. and Lekkas, T. (1999) Forecasting Daily Maximum Ozone Concentrations in the Athens Basin. Environmental Monitoring and Assessment, 56, 97-112. http://dx.doi.org/10.1023/A:1005943201063

[33] Papanastasiou, D.K. and Melas, D. (2008) Daily Ozone Forecasting in an Urban Area, Using Meteorological and Pollution Data. Fresenius Environmental Bulletin, 17, 364-370.

[34] Sousa, S.I.V., Martins, F.G., Alvim-Ferraz, M.C.M. and Pereira, M.C. (2007) Multiple Linear Regression and Artificial Neural Networks Based on Principal Components to Predict Ozone Concentrations. Environmental Modelling and Software, 22, 97-103. http://dx.doi.org/10.1016/j.envsoft.2005.12.002

[35] Barrero, M.A., Grimalt, J.O. and Canton, L. (2006) Prediction of Daily Ozone Concentration Maxima in the Urban Atmosphere. Chemometrics and Intelligent Laboratory Systems, 80, 67-76. http://dx.doi.org/10.1016/j.chemolab.2005.07.003

[36] Tecer, L.H., Erturk, F. and Cerit, O. (2003) Development of a Regression Model to Forecast Ozone Concentration in Istanbul City, Turkey. Fresenius Environmental Bulletin, 12, 1133-1143. 
Scientific Research Publishing (SCIRP) is one of the largest Open Access journal publishers. It is currently publishing more than 200 open access, online, peer-reviewed journals covering a wide range of academic disciplines. SCIRP serves the worldwide academic communities and contributes to the progress and application of science with its publication.

Other selected journals from SCIRP are listed as below. Submit your manuscript to us via either submit@scirp.org or Online Submission Portal.
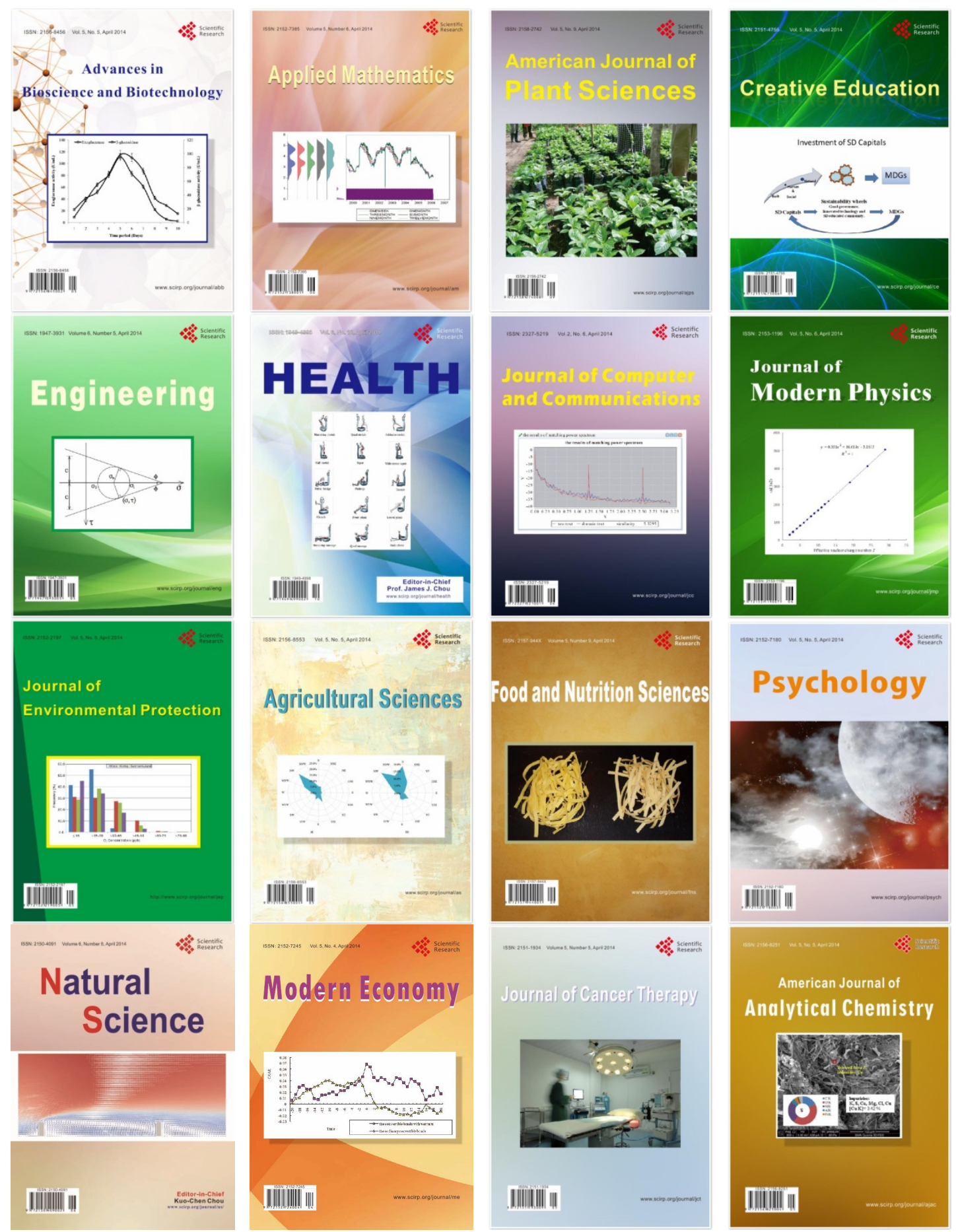